\title{
IDENTIFYING THE BLOCK PATTERN OF SKOPJE'S OLD BAZAAR
}

\author{
- Analysis of blocks' development, typology and transformation -
}

\author{
スコピエ・オールド・バザールにおける街区パターン \\ 一街区の発展，類型㧍よび変容に関する分析一 \\ Aleksandra KRSTIKJ* and Hisako KOURA** \\ アレクサンドラクルスティック，小浦久子
}

\begin{abstract}
Today the block pattern of Skopje's Bazaar, created by the Ottoman urban strategy during the $15^{\text {th }}$ and $16^{\text {th }}$ century, is only partially understood. The aim of this paper is to identify the block typology of the Old Bazaar by analyzing the relations between form and development. To meet the aim, we analyzed previous research, Skopje's map from 1929 and conducted field survey (09/2011). Based on the data from 1929 map, we identified two other subtypes of facility blocks from the one facility and three shop blocks described in previous research. Most of the surviving blocks still preserve their shape and structure although in some cases an alteration of the block type occurred as a result of the destruction of Ottoman facility or shop rebuilding. We concluded that the historic urban order of the ground plan and the block pattern, created by the systematic relationships of facility, shop and street in the Ottoman urban strategy, are important values of the Bazaar's urban form. As the pressure for modern development surges, the results of this study can facilitate creation of design guidelines for sustainable conservation of the urban form of Skopje's Bazaar.
\end{abstract}

Keywords : Skopje’s Bazaar, block development, block typology, structure of block, block transformation スコピエ・バザール, 街区発展, 街区類型, 街区の構造, 街区変容

\section{Introduction}

The modernization and rapid urban growth of the $20^{\text {th }}$ century altered the urban structure of Skopje's historic urban center - the Old Bazaar, developed by the Ottomans during the $15^{\text {th }}$ and $16^{\text {th }}$ century ${ }^{1,2), 3)}$. Although Skopje's Bazaar was designated Cultural Heritage of Significant Importance by the Macedonian Ministry of Culture in 20084), a clear planning strategy for conservation hasn't been created yet. With the intensification of the economic development, the threat to the still preserved cultural and historic resources is increasing. This study focused on the spatial structure of blocks in Skopje's Bazaar in order to support sustainable planning and conservation policies that can regulate new development without compromising the values of the historic urban form.

\subsection{Research aim}

Today the block pattern of Skopje's Bazaar is only partially understood. Previous research described some types of blocks in the Bazaar but no explanation is offered regarding the variations of block structure or process of development. Therefore, the aim of this paper is to clearly identify the block pattern of Skopje's Old Bazaar by analyzing the relations between form and development. A clear understanding of the blocks' formation process, morphological attributes and recent transformations can contribute in creating design guidelines for successful conservation of Skopje's Bazaar.

\subsection{Previous research and originality of our study}

Although previous research on block typology in Arabic-Islamic cities (Hakim, 1988)5) reveal many similarities with the blocks in Ottoman Skopje, a case-study research is necessary to better understand the specific attributes of Skopje's Bazaar blocks. Skopje's Bazaar block typology has been shortly covered in the Revalorization Report by the National Institution-Conservation Center Skopje (2006)6) and Mateska's study $(2011)^{7)}$ where 4 types of Bazaar blocks were described. However, based on Skopje's 1929 map and our field survey (2011), we observed variations of the block types covered in previous research as well as recent transformations. Thus, our study focused on identifying the block pattern of Skopje's Bazaar by analyzing the blocks' development and recent transformations.

\subsection{Methodology}

The method for this study was based on document analysis and field survey. The documents include: previous research on Skopje's pre-Ottoman urban form (Institute for Urbanism and Arch.-Skopje 19671), Arsovski 19882)); urban form of cities in the Muslim world (Hakim 19885), Stern 19708), Hourani 19709), André 198410); Ottoman urban strategy in Bazaars' development

\footnotetext{
* Ph. D. Graduate, Graduate School of Engineering, Osaka Univ.

** Assoc. Prof., Graduate School of Engineering, Osaka Univ., Dr. Eng.
}

大阪大学大学院工学研究科 博士 (工学)

大阪大学大学院工学研究科 准教授·博士 (工学) 
(Cezar 198311), Boykov 201121) and Skopje's Bazaar urban form and structure (Institute for Urbanism and Arch.-Skopje 19671), Arsovski 19882), N.I.- Conservation Center Skopje (2006)6), Mateska 20117), Bogoević 199813)). Moreover, we used a map of Skopje from 1929, taken from the Archive of Macedonia in Skopje. The map was produced by the experts in the Cadastral Municipality Office-Skoplje to facilitate a creation of a Master Plan by Mihajlović in 1929.

The field survey was performed by the authors and graduate students of the laboratory of Japanese Architecture in Kyoto Institute of Technology (prof. Hyuga) during $12^{\text {th }}-23^{\text {th }}$ 09.2011. The survey focused on six blocks in Skopje's Bazaar located along the Main Bazaar Street. The data was collected by sketching and measurement of the blocks' shape and size, as well as documentation of the lot and building distribution.

\section{Ottoman urban strategy of developing Bazaars}

We analyzed previous research to clarify the Ottoman urban strategy in developing Bazaars as urban centers. According to Stern (1970), the urban form of cities in the Muslim world differs from western European ones as a result of absence of professional or corporate organizations and municipal institutions in the Islamic societies ${ }^{8}$. Thus the non-existence of a square surrounded by municipal buildings is strongly connected with centralized state and low autonomy of the city ${ }^{8}$. Hourani (1970) defined the Bazaar with the Main Mosque as a central urban complex in the Muslim city, surrounded by residential quarters $^{9}$. Moreover, André (1984) defines the remarkable growth of the commercial centers under the Ottoman Empire, carried out by succession of pashas, as: “...systematic process within a general plan of development..."10). This consistent process can be described through the following stages:

1. Founding of Main Friday Mosque;

2. Founding of Bedesten; there is no exception in locating the Bedesten, crucial for international trade, in vicinity of the Main Mosque thus forming the urban center;

3. Developing a Main Bazaar Street aligned by shops. This street usually took over a major thoroughfare where the Main Mosque and the Bedesten were located. Other facilities were founded along the Main Street and promoted Bazaar's urbanization;

4. Developing secondary Bazaar streets by conversion of residential into commercial sectors ${ }^{10), 11), 12) .}$

Therefore, the public facility is the main instrument to promote Bazaar's development in the Ottoman urban strategy.

\section{Influence of former land use patterns}

Skopje was conquered by the Ottoman Empire in 13921),2). The purpose of this discussion is to clarify how the Bazaar's development was influenced by the former land use patterns and the road network in Skopje.

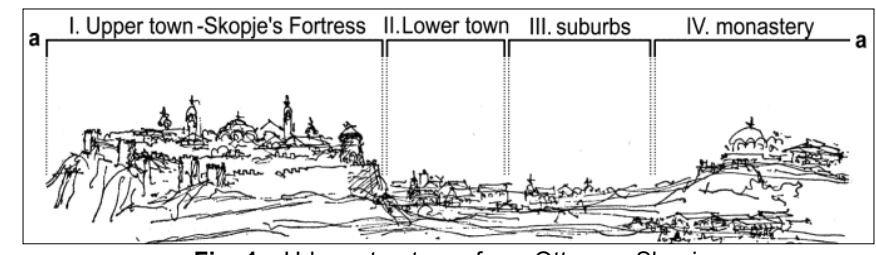

Fig. 1 Urban structure of pre-Ottoman Skopje

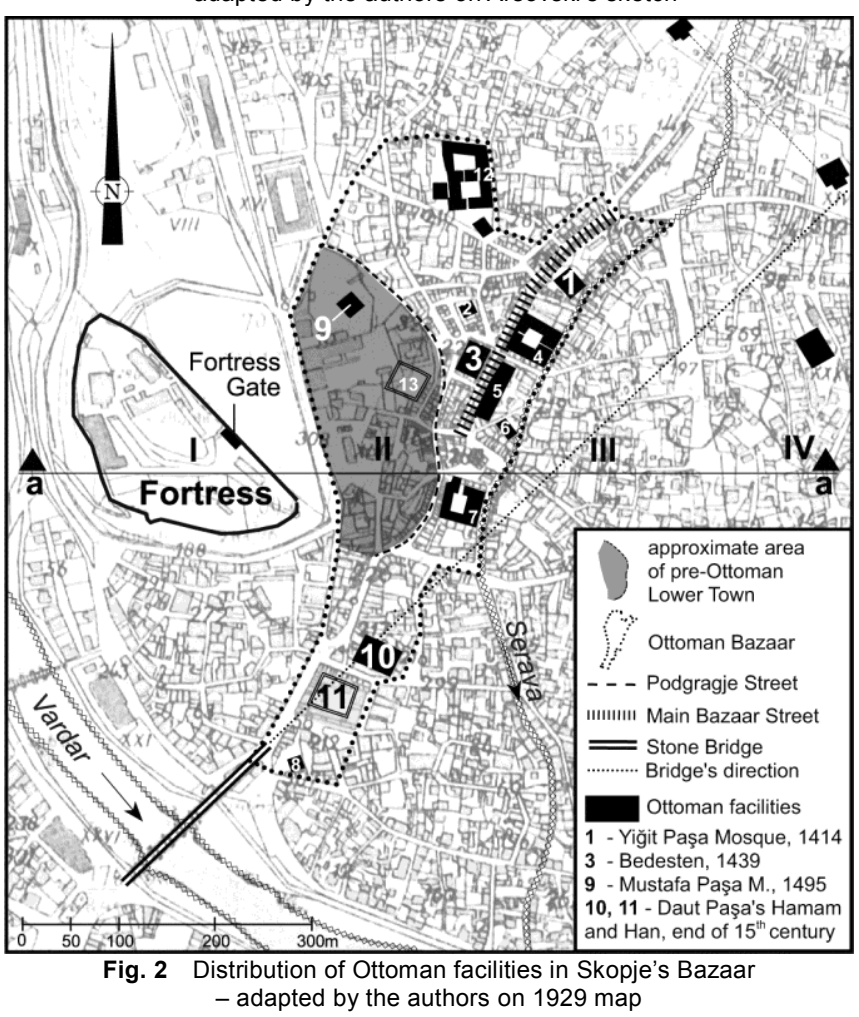

In previous research, pre-Ottoman Skopje is described as a settlement laid out between the Fortress hill on the west, river Vardar on the south and river Serava on the east ${ }^{1), 2}$. It was composed of strongly fortified Upper Town - Skopje's Fortress (I), fortified Lower Town on the east slope of the Fortress hill (II) and unfortified suburbs in the valley (III)1),2) (Fig. 1/a-a). There is a lack of archeological and historical data that can clearly indicate the urban form of the Lower Town and its wall before the Ottomans. However, it is quite sure that the existing Lower Town influenced the decision of sites for the first Ottoman facilities that identified the urban center since the consistent Ottoman strategy was not to destroy the conquered settlement in the beginning but to gradually dismantle and restructure it ${ }^{12)}$.

According to Cezar (p.31, 1983), in the conquered cities of the Balkans, the Ottoman Bazaar took over a previous market place or developed in a part most suitable for development, usually along the outer side of the former fortification wall where the regional highways traversed (Edirne) ${ }^{11)}$. In Skopje, the Ottomans started developing the Bazaar from the first Mosque Yiğit Paşa in 14143),12) (Fig. 2/1). The first Ottoman facilities were founded in the valley of river Serava, where the former suburbs were located ${ }^{1,2)}$ (Fig. 2/1-7). Since the Bedesten's site (Fig. 2/3) is closest to the Fortress Hill's slope we can assume this location as 
an edge of the pre-ottoman Lower Town. Thus, the unique curving line of street Podgragje (Fig. 2) could be close to the outline of Lower Town's fortification wall. The Lower Town's area finally started to develop 100 years after the Ottoman conquest, with the building of Mustafa Paşa's Mosque in 14953) (Fig. 2-9).

The direction of the Stone Bridge, built in the early stage of Ottoman rule (Sultan Murad II: 1421-1451)13), is also interesting since it seems to be oriented not towards the Main Bazaar Street's segment already formed at that time by the first Ottoman facilities (Fig. 2/1,2,3,4) but into Daut Paşa's buildings from the late $15^{\text {th }}$ century (Fig. $2 / 10,11$ ). This seems to suggest that the connection to the existing regional highway network was the most significant factor in deciding the Bridge's location and direction in early times. As the Main Bazaar Street continued to develop in the following years, the locations of Daut Paşa's buildings could have been used to reorient the traffic from the Bridge's old route towards the Main Bazaar Street. However, more archeological and historical research is needed to clarify in detail how this redevelopment proceeded.

\section{Block pattern of Skopje's Old Bazaar}

\subsection{Origin of Skopje's Bazaar urban blocks}

We do not have precise historical data regarding the structure of blocks in Skopje's Bazaar in $15^{\text {th }}-16^{\text {th }}$ century. However, the chronology and location of Ottoman facilities founded in five consecutive historical periods during 1392-1550 can be understood from Fig. 6 in Krstikj, Koura 20133). Even though the exact shape and size of blocks developed in those periods is unknown, according to the chronology of Ottoman facilities in Skopje's Bazaar, we can at least define the timeline of initiation of those blocks that included a facility. It seems logical to assume that the initiation of Bazaar's blocks composed solely from shops must have been shortly after the establishment of the nearest public facility since the facilities carried out the urbanization process. Thus, the chronology and location of Ottoman facilities can indicate the process of block development.

In the first period, the blocks containing the Main Mosque Yiğit Paşa and Arasta Mosque were initiated ${ }^{3)}$ (Fig. 3/I). Between those two blocks the Main Bazaar Street, part of the regional network of Skopje ${ }^{3)}$, started to form. In the second period, the Bedesten and Suli Han blocks were initiated and that further extended the Main Bazaar Street to the south (Fig.3/II). The development of Main Bazaar Street continued in the third period and was finally formed in the fourth period with gradual inception of facility block structures towards the south and the Stone Bridge (Fig. 3/III,IV). In the fifth period, the northwest section of the Bazaar was formed with the large Kurşumli Han and Kjurçi Han blocks (Fig. 3/V). Fig. 3 shows the chronological development of blocks however, the shapes of the blocks in this figure are from the 1929 map. It is likely that some blocks, especially blocks without a facility, to have had different form before 1929. Thus, with this analysis we identified the origins of Skopje's Bazaar urban blocks from 1392 to 1550, although the blocks' shape and size in these period are unknown.

\subsection{Typology of blocks}

In Mateska's book (2011), one facility block and three types of shop blocks in Skopje's Bazaar are described ${ }^{7)}$. Our analysis of the blocks' structure based on the 1929 map revealed two other variations of facility blocks. Thus, in this chapter we present a more detailed typology of Skopje's Bazaar blocks.

The blocks can be categorized in two basic types (Fig. 4): - type A : block with public facility lot enclosed by row of shops; - type B: block without facility and composed solely by shops.

The facility block defined in previous research ${ }^{7)}$ is: subtype AII - block that contains facility building in the central part of the block. The facility is surrounded by shops structurally

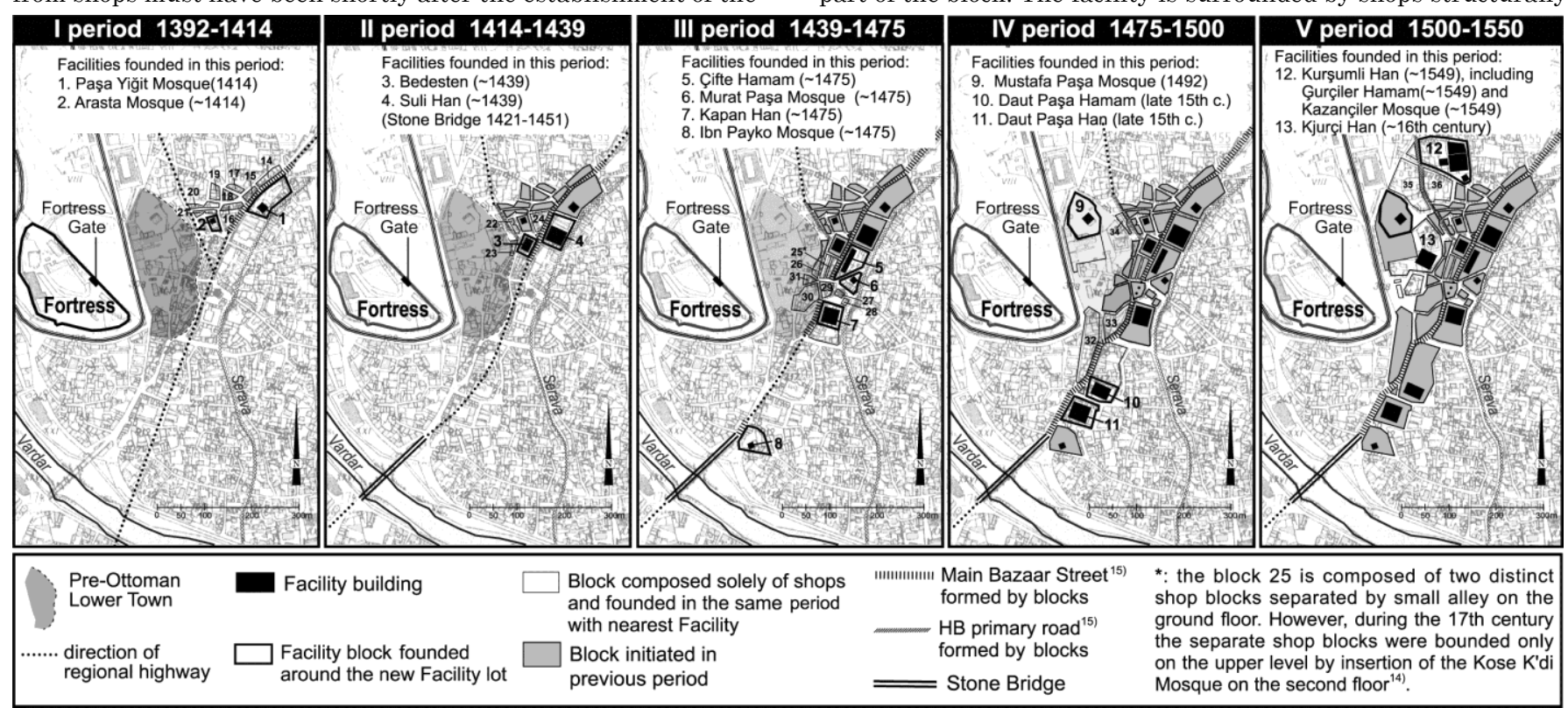

Fig. 3 Process of block development in Skopje's Bazaar based on chronology and location of Ottoman public facilities (blocks' outline from 1929 map) 


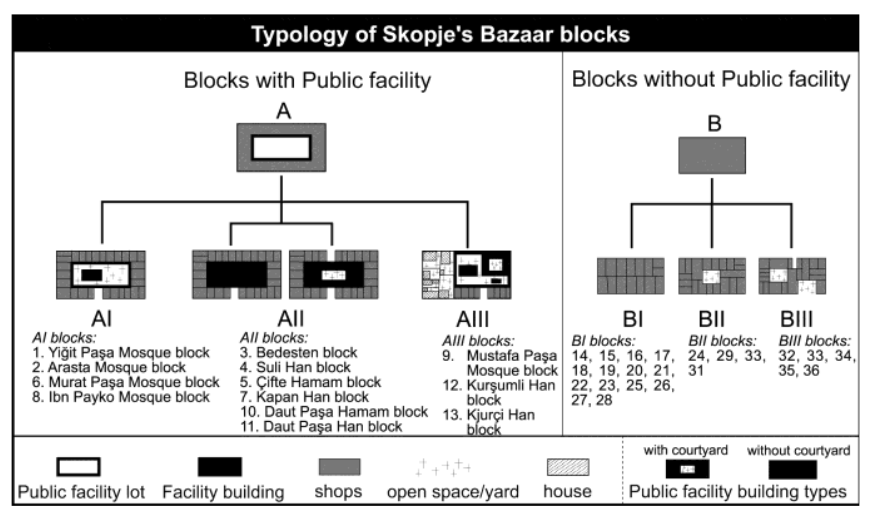

Fig. 4 Block types in Skopje's Bazaar based on 1929 map

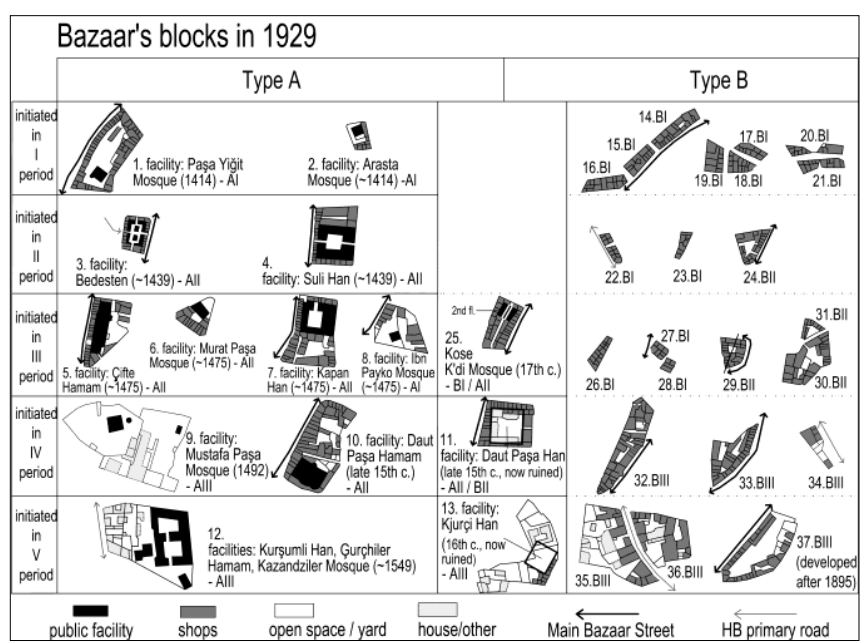

Fig. 5 Structure of blocks in Skopje's Bazaar based on 1929 map

Table 1 Scale of Skopje's Bazaar block subtypes

\begin{tabular}{|c|c|c|c|c|c|c|c|}
\hline & AI & AII & AIII & $\mathrm{BI}$ & BII & BIII \\
\hline \multicolumn{2}{|c|}{ blocks from I period } & 2 & & & 8 & & \\
\hline \multicolumn{2}{|c|}{ blocks from II period } & & 2 & & 2 & 1 & \\
\hline \multicolumn{2}{|c|}{ blocks from III period } & 1 & 3 & & 4 & 3 & \\
\hline \multicolumn{2}{|c|}{ blocks from IV period } & & 2 & 1 & & & 3 \\
\hline \multicolumn{2}{|c|}{ blocks from $\mathrm{V}$ period } & & & 2 & & & 2 \\
\hline \multicolumn{2}{|c|}{ blocks total } & 3 & 7 & 3 & 14 & 4 & 5 \\
\hline \multirow{3}{*}{ Length* } & $\max$. & 117.4 & 120.5 & 121 & 61 & 73.5 & 130 \\
\hline & $\min$. & 32.4 & 45 & 90 & 15 & 23.4 & 49 \\
\hline & average & 74.9 & 82.75 & 105.5 & 38 & 48.45 & 89.5 \\
\hline \multirow{3}{*}{ Width* } & max. & 66.7 & 65 & 70 & 27 & 42 & 60 \\
\hline & $\min$. & 20.8 & 32.5 & 33.2 & 9 & 26 & 18 \\
\hline & average & 43.75 & 48.75 & 51.6 & 18 & 34 & 39 \\
\hline \multicolumn{2}{|c|}{ length/width ratio } & 1.7 & 1.7 & 2 & 2.1 & 1.4 & 2.3 \\
\hline \multicolumn{2}{|c|}{$\begin{array}{l}\text { diagram of approx. scale } \\
\text { relative to other subtypes }\end{array}$} & 물 & & 블믐 & 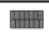 & se & tat \\
\hline
\end{tabular}

connected with their rear wall to the facility's façade (Fig. 4-AII).

However on the 1929 map, we detected two other subtypes of distinct facility blocks that differ in the structural relationship of the facility building with the other buildings of that block:

subtype AI - block that contains a facility lot in the central part of the block. The facility building/s is/are free standing in the lot and detached from surrounding shops (Fig. 4-AI);

subtype AIII - block with loosely built structure composed of facility lot with one or several facility buildings and a group of sparsely built lots (residential or other). On one side of the facility lot, a group of several shops can be attached (Fig. 4-AIII).

The three shop blocks defined in previous research ${ }^{7)}$ differ in the density of the built up area and continuity of the street-front: subtype BI - fully built block containing two rows of shops
Table 2 Transformation of 6 blocks in Skopje's Bazaar 1929-1999-2011

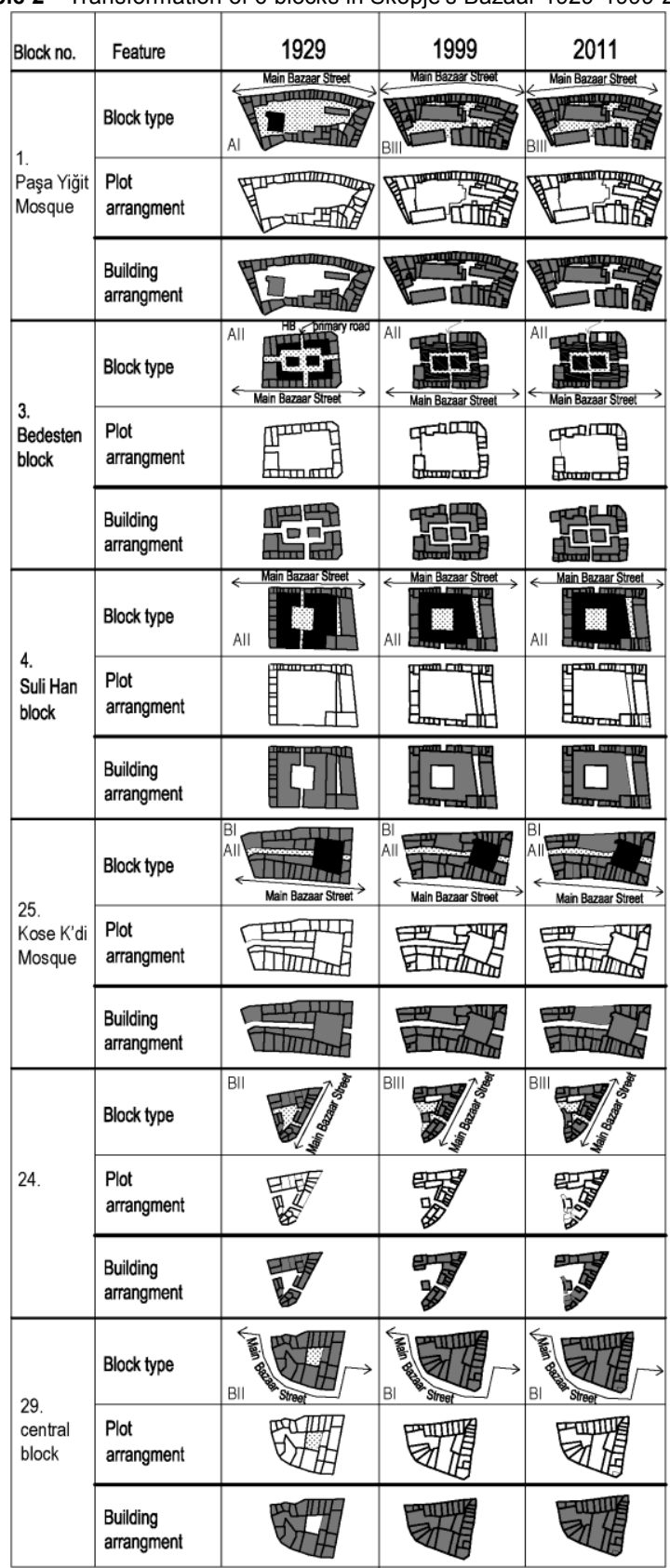

attached back-to-back (Fig. 4-BI);

subtype BII - block with a common central yard enclosed by shops attached in a row (Fig. 4-BII);

subtype BIII - block with multiple yards, loosely built area and some detached or semi-detached shops. According to Mateska ${ }^{7)}$, this block subtype is a deteriorating BI or BII block (Fig. 4-BIII).

\subsection{Morphology and scale of blocks}

We analyzed the morphology of blocks presented in the 1929 map in relation to their historical period of initiation (Fig. 5):

1. The block subtypes seem to change from AI-AII-AIII and BI-BII-BIII in relation to their chronology of initiation.

2. Facility blocks initiated in the I period $(1,2)$ are subtype AI while the blocks initiated in II, III and IV period are subtype AII with exception of block Ibn Payko Mosque (8). It is possible that 


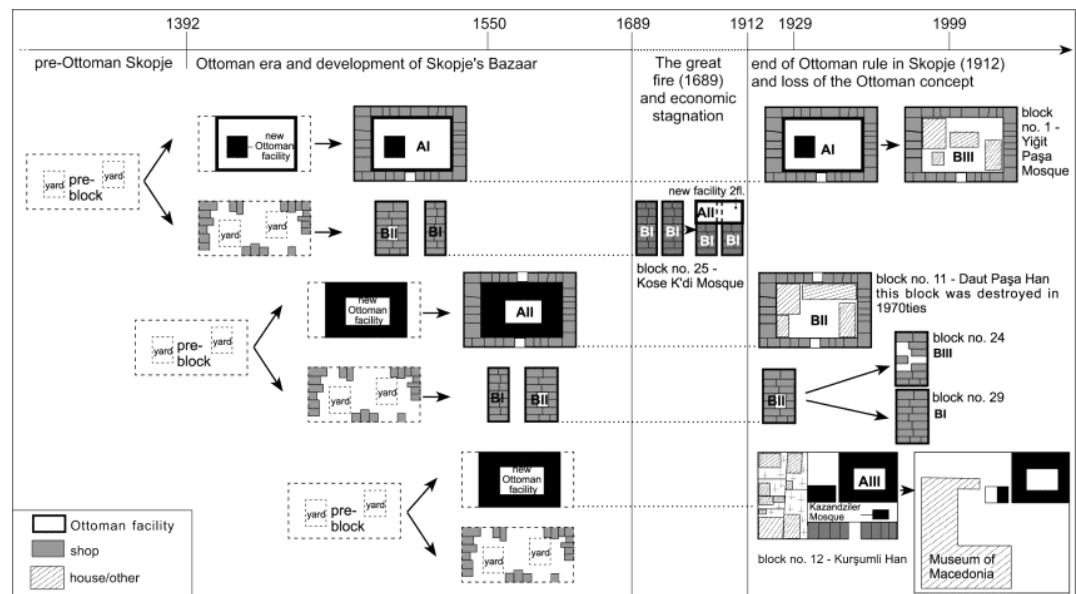

Fig. 6 Block pattern evolution in Skopje's Bazaar

subtype AI was preferred for blocks containing a Mosque to ensure the tranquility of religious ceremonies. The AIII blocks are the last ones initiated in the Bazaar. In the 1929 map, these blocks also include some houses or other buildings in the Bazaar's outskirts, thus we assume that their formation or restructuring from residential into Bazaar block in the $16^{\text {th }}$ century was unfinished and later deteriorated into subtype AIII.

3. Shop blocks from I, II and III periods are subtype BI and BII while blocks from later periods are BIII and even contain some houses in the outskirts. This is consistent with the possibility that the restructuring of blocks from later periods was unfinished or partial although, in some cases BIII can be a deteriorating $\mathrm{AI}$ or BII blocks (Table 2-block 1, 24).

4. Kose K'di Mosque (25) and Daut Paşa Han (11) blocks are exemplars of transformation of one block type into another. In Kose K'di block, a longitudinal alley separates two independent BI blocks on the ground floor. The Kose K'di Mosque located on the second floor of the block was built in the $17^{\text {th }}$ century ${ }^{13)}$, most likely after the two BI blocks were already formed. Thus, a hybrid block structure was formed of two BI blocks on the first floor and AII block on the second. On the other hand, Daut Paşa Han block was formed as AII block but later lost the facility building ${ }^{13)}$. The facility lot was overtaken by auxiliary and shop buildings thus in 1929 the block was already altered to BII.

5. The Kapan Han (7) and Daut Paşa Hamam (10) blocks have a large area of shops attached to one side of the block. These shops are grouped around an inner yard thus, it seems like a BII block became attached to a neighboring AII, probably after an alley that separated them was closed up by auxiliary buildings.

6. The block 29 (BII) on the 1929 map seems to be obstructing the linear extension of the Main Bazaar Street. However, we don't know the exact shape of the shops blocks and the precise outline of the Main Bazaar Street during the early periods of Bazaar's development. More maps and historical research is needed to clarify the shape and position of this block in relation to the Main Bazaar Street.
Further, we analyzed the scale of blocks based on the data from the 1929 map and our own field survey. The size of blocks taken from the 1929 map are considered approximate because the preciseness of the survey method cannot be confirmed. The maximum length and width of each block was analyzed to determine the average scale of each block subtype (Table 1). We concluded that blocks subtype AI and AII have similar size and are slightly elongated. The AIII and BIII blocks are largest blocks in the Bazaar. The BI blocks are the smallest, with area five times smaller than BIII's and eight times smaller than AIII's.

\subsection{Transformation of block structure 1929-1999-2011}

During the $20^{\text {th }}$ century, the modernization ignored the Ottoman concept in Skopje's historic urban center ${ }^{3)}$. Six blocks from 1929 map were compared with the same blocks in 1999 and 2011 (Table 2). The 1999 data was obtained from the National Institution-Conservation Center Skopje, while the 2011 data was obtained from our own field survey. From the data we concluded that major changes in the blocks' size and shape didn't occur. However some transformations in block type, plot and building arrangement were detected. The block type transformation involved a change of AI to BIII in block 1, due to the destruction of Yiğit Paşa Mosque inside the block in 194513). On the other hand, the shop blocks altered the typology in two ways: gradual deterioration of some shops brought about alteration of the block subtype of BII to BIII in block 24; and building up of the central yard altered the block subtype of BII to BI in block 29 .

The plot and building arrangements usually coincide in the Bazaar's blocks because of fully built up lots. In 2011, the loss of several shop buildings in blocks 1, 3 and 24 was noticed. However, these shops were not located on the Main Bazaar Street. In the Bedesten (3), the blocking of HB primary road on the west side by the Museum of Macedonia in 19701),3) probably contributed to the abandoning and decay of shops on that block side. In blocks 4 and 25 , a unification of few shops in one lot/building occurred on the block side opposite of the Main Bazaar Street. However, a different trend was noticed in all block fronts that face the Main Bazaar Street where the shop density increased by dividing some shops on two or more units. Thus, though the modernization altered the traffic of the historic center, the Main Bazaar Street still effects plot and building distribution patterns in the Bazaar.

\subsection{Evolution of the block pattern of Skopje's Bazaar}

Based on the above analysis, the evolution process of Skopje's Bazaar block pattern was clarified (Fig. 6). The development progressed with the founding of Ottoman facilities on empty land or in already existing pre-blocks. The facility attracted shops around its lot thus, facility block type A were gradually formed. In the facility's vicinity, B type blocks formed from the 


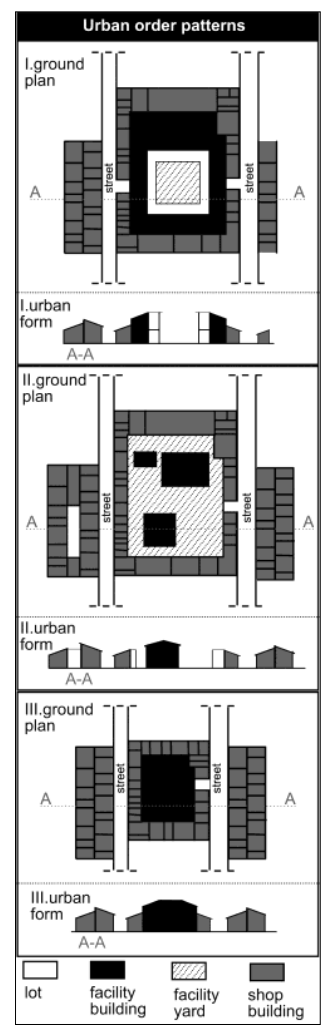

Fig. 7 Historic urban order congregation of shops on empty land or by conversion of previous residential pre-blocks. The conversion progressed by gradual installment of shops around the pre-blocks' perimeter. In the restructuring process, it is likely that the any pre-block would have been split on several shop blocks since the size of $\mathrm{BI}$ and BII blocks is quite small. This process recurred with each Ottoman facility founded in the Bazaar. The unique case of Kose K'di Mosque built in the $17^{\text {th }}$ century on the $2^{\text {nd }}$ floor of two adjacent shop blocks is exemption from this strategy (Fig. 6/25). Most of A blocks are along the Main Bazaar Street thus the outline of this street was formed by the $16^{\text {th }}$ century and remained unchanged until the Bazaar's Reconstruction in 19701,2,3).

Until the $20^{\text {th }}$ century, significant changes to A blocks seem unlikely because the facility, as a main structural element of the block, remained. Even when some facilities were destroyed after the Ottoman army retreated from Skopje (1912), the block kept its main shape but altered the block type into BII or BIII (Fig. 6/1, 11). In case of Kurşumli Han block (Fig. 6/12), its partially developed structure from the late $16^{\text {th }}$ century was transformed by the Reconstruction in the 1970ties that demolished the Kazandziler Mosque and the buildings in the west part of the block ${ }^{1,3)}$. The Kurşumli Han was included in the new block of Museum of Macedonia ${ }^{1), 3)}$. This transformation weakened the Ottoman concept of the Bazaar's block pattern. Some alterations of B blocks occurred as a result of rebuilding of shops (Fig. 6/24, 29). Thus, even though the modernization altered the Bazaar's urban layout ${ }^{1,3)}$, the block pattern in Skopje's Bazaar is mostly preserved.

\section{Conclusion}

The block pattern of Skopje's Bazaar originates from the $15^{\text {th }}-16^{\text {th }}$ century. It was developed by the Ottoman strategy that utilized locations of public facilities to promote urbanization and redevelopment. Based on data from Skopje's 1929 map, we identified two other subtypes of facility blocks from the one facility and three shop blocks described in previous research. The block subtypes found on the 1929 map seem to be related to the period of blocks' origin. For example, the blocks initiated in the latest periods of Bazaar's development are largest and loosely built while the blocks from early phases are smaller and denser.

Based on our analysis of the blocks' development and structure, we concluded the presence of historic urban order of the ground plan, created by the systematic relationships of facility, shop and street in the Ottoman urban strategy (Fig. 7). The historic urban ordering produce the block pattern in Skopje's Bazaar. Thus, the historic urban order and the block pattern are important values of the urban form of Skopje's Bazaar.

Even though the modernization obscured the Ottoman concept in Skopje's Bazaar, the historic urban order and block pattern are still preserved. However, as the pressure for new development surges with the economic growth, the threat to the preserved historic resources increases. The results of this study can facilitate the creation of design guidelines for conservation of the block pattern and urban form of Skopje's Bazaar.

\section{References}

1) Institute for Urbanism and Architecture - Skopje: Стара чаршија (Old Bazaar), 1967 (in Macedonian)

2) Arsovski, Т.: Старо Скопје, (Old Skopje), Skopje's Committee for Urbanism, 1988 (in Macedonian)

3) Krstikj, A., Koura, H.: Identifying the significance of historic place in Skopje's Old Bazaar - Based on analysis of facility's location and primary road in the Ottoman urban strategy -, J. Archit. Plann., AIJ, Vol. 78 No. 686, pp. 829-835, 2013.4

4) Службен весник на Република Македонија (Official gazette of Republic of Macedonia), No.130, Year LXIV, 2526, 15.10.2008, pp. 6-13 http://www.slvesnik.com.mk/Issues/788085D60367EB4196670B798E3 B989A.pdf, accessed 29.07.2013 (in Macedonian and Albanian)

5) Hakim, S. B.: Arabic-Islamic Cities-building and planning principles, Kegan Paul International, London, 1988

6) Revalorization Report of Old Skopje's Bazaar, National Institution Conservation Centre - Skopje, 2006 (in Macedonian)

7) Mateska, G. S.: Bazaar in the Architectural and Urban structure of Towns in R. Macedonia, Cultural and Historic Heritage of R. Macedonia LVII ed., N.I.-Conservation Centre Skopje, 2011 (in Macedonian, summary in English)

8) Stern, S.M.: The Constitution of the Islamic city, The Islamic city Papers on Islamic History I, ed. Hourani, A.H.\&Stern, S.M., Bruno Cassirer Oxford and Uni. of Pennsylvania Press, pp. 25-49, 1970

9) Hourani, A.H.: The Islamic city in the light of recent research, The Islamic city-Papers on Islamic History I, ed. Hourani, A.H.\&Stern, S.M. Bruno Cassirer Oxford and Uni. of Pennsylvania Press, pp. 9-24, 1970

10) André, R.: The Great Arab Cities in the $16^{\text {th }}-18^{\text {th }}$ century, Hagop Kevorkian series on Near Eastern art and civilization, New York University Press, New York, 1984

11) Cezar, M.: Typical Commercial Buildings of the Ottoman Classical Period and the Ottoman Construction System, Türkiye Iş Bankasi Cultural Publications, Istanbul, 1983

12) Boykov, G.: Reshaping urban space in the Ottoman Balkans: study on the architectural development of Edirne, Plovdiv and Skopje (14-15 century), Centers and Peripheries in Ottoman Arch.: Rediscovering Balkan Heritage, Max. Hartmuth ed., Sarajevo, pp. 32-45, 2011

13) Bogoević-K., L.: Османлиски споменици во Скопје (Ottoman monuments in Skopje), Исламска заедница во PM-Скопје, Сектор за наука и исламска култура, 1998 (in Macedonian)

14) Sokoloski, M.: Les Biens des vaqyf a Skopje et dans la region environnante au XVe et XVI ${ }^{e}$ siecle, Contributions of the Macedonian Academy of Science and Arts, Vol. 8/2, pp. 27-82, Skopje, 1977 (in Macedonian, summary in French)

15) Krstikj, A., Hyuga, S., Koura, H.: Study on typology of shops and their transformations in Skopje's Old Bazaar - based on analysis of vernacular units' form and design elements, J. Archit. Plann., AIJ, Vol. 77 No. 678 , pp. 1881-1887, 2012.8 


\section{和文要約}

オスマンの都市戦略に基づいて形成されてきた中心地区を構 成する街区構造について、街区の空間形態の特徴と市街化履歷から 類型を試みた。その結果、中心道路沿道に立地する主要な公共施設 (モスク・八マム等）の立地を核にその周りに店舖が建設されてい くタイプAと、この街区形成に連動するように隣接して店舗が集合 して建設されることによって形成されると考えられるタイプBを確 認した。いくつかの街区は長い年月の間にこの基本の構造を衰失し ているものが見られる。また、バザールの中心道路敒面する街区と それ以外の街区では変容のパターンに違いが見られた。中心道路に 面する街区では宅地分割が見られ、その他では空地化や宅地の併合 が見られた。

（2013年 7 月 10 日原稿受理， 2014 年 3 月 5 日採用決定） 